\title{
Implementasi Penilaian Portofolio di Taman Kanak- kanak Era Pandemi COVID-19
}

\author{
Iin Maulina ${ }^{1 凶}{ }^{\natural}$ Hazilina $^{2}$ \\ Pendidikan Guru Pendidikan Anak Usia Dini, Universitas Muhammadiyah Pontianak, \\ Indonesia(1); Ilmu Hukum, Universitas Muhammadiyah Pontianak, Indonesia(2) \\ DOI: $10.31004 /$ obsesi.v6i4.2396
}

\begin{abstract}
Abstrak
Penelitian ini dilatarbelakangi oleh pandemi COVID-19 yang terjadi, sehingga mempengaruhi metode pengajaran yang dilakukan oleh guru di Taman Kanak-kanak (TK). Metode pengajaran yang digunakan selama masa pandemi COVID-19 adalah pemberian tugas. Tugastugas yang dikerjakan anak-anak usia dini di rumah dijadikan penilaian guru-guru dalam menyusun raport atau hasil belajar anak. Oleh karena itu, penelitian ini bertujuan untuk mendeskripsikan analisis penilaian portofofolio yang dilaksanakan di TK. Metode penelitian ini adalah metode deskriptif kualitatif dengan teknik pengumpulan datanya, meliputi: observasi, wawancara, dan dokumentasi. Adapun teknik analisis datanya yaitu analisis deskriptif. Hasil penelitian berdasarkan analisis perencanaan dan pelaksanaan dari kegiatan penilaian yang dilakukan oleh guru berkaitan dengan tugas-tugas anak secara menyeluruh dinyatakan "baik". Implikasi penilaian portofolio di TK adalah mampu memberi gambaran atau pandangan tentang kemampuan anak, sebagai catatan jangka panjang, dan membantu mengidentifikasi kelemahan, kelebihan, dan merancang strategi mencapai kompetensi peserta didik yang diharapkan.
\end{abstract}

Kata Kunci: penilaian; portofolio; taman kanak-kanak

\begin{abstract}
This research was motivated by the COVID-19 pandemic that occurred, thus affecting the teaching methods carried out by teachers in kindergarten. The teaching method used during the COVID-19 pandemic is assignment. The tasks done by early childhood at home are used as an assessment of teachers in preparing the child's learning outcomes. Therefore, this study aims to describe portofofolio assessment analysis conducted in kindergarten. This research method is a qualitative descriptive method with its data collection techniques, including: observation, interview, and documentation. The data analysis technique is descriptive analysis. The results of the study based on the analysis of planning and implementation of assessment activities carried out by teachers related to children's tasks are thoroughly declared "good". The implication of portfolio assessment in kindergarten is that it is able to provide an overview or view of the child's abilities, as a long-term record, and help identify weaknesses, advantages, and design strategies to achieve the expected competence of learners.
\end{abstract}

Keywords: assessment; portfolio; kindergarten

Copyright (c) 2022 Iin Maulina, et al.

$\square$ Corresponding author:

Email Address : iinmaulina876@gmail.com (Pontianak, Indonesia)

Received 7 November 2021, Accepted 25 February 2022, Published 25 February 2022 


\section{PENDAHULUAN}

Dunia saat ini sedang tidak baik-baik saja. Bencana pandemi saat ini menimpa seluruh lapisan masyarakat di dunia. Hal ini karena adanya serangan dari virus COVID-19 yang berawal dari Wuhan, China (Chiodini, 2020). Keadaan ini berlangsung sejak 2019 hingga sekarang. Perubahan dan semakin banyaknya varian virus semakin lama semakin meresahkan masyarakat (Lučić, 2020). Terutama keadaan masyarakat yang terjangkit setiap bulan mengalami kenaikan atau penurunan yang dinamis sepanjang 2019 sampai sekarang (Satgas COVID-19, 2021). Selain masalah kesehatan, yang ikut terdampak adalah sektor pendidikan. Tidak terkecuali pada pendidikan anak usia dini.

Pendidikan anak usia dini diarahkan pada pembentukan kecerdasan anak sehingga seharusnya dapat tumbuh dan berkembang dengan baik. Akan tetapi anak saat ini mengalami banyak gangguan terutama dalam pembelajaran selama COVID-19 (Suyadi \& Selvi, 2022). Gangguan dalam pembelajaran terutama pembelajaran online mempengaruhi berbagai aspek perkembangan anak. Padahal pendidikan anak usia dini diarahkan sebagai wadah pembentukan kecerdasan anak sehingga dapat tumbuh dan berkembang dengan optimal (Tommasel et al., 2019). Akibatnya keadaan kehidupan yang terjadi saat ini, khawatir akan mempengaruhi perkembangan anak di masa mendatang.

Pemerintah saat ini berupaya menerapkan strategi dan metode pengajaran yang melalui guru-guru pendidikan anak usia dini (Oktaviana \& Srianggita, 2021). Strategi dan metode pengajaran dilaksanakan secara daring. Dalam rangka mencegah penyebaran COVID19, aktivitas pembelajaran dilaksanakan di rumah melalui aplikasi yang tersedia, seperti: video conference, digital document atau sarana lainnya yang memadai proses pembelajaran daring (Fauziddin et al., 2021). Hal ini karena, untuk mengurangi dampak terjangkit virus COVID-19 dengan melakukan pembatasan sosial atau tatap langsung (Menteri Kesehatan RI, 2020). Perubahan strategi dan metode pengajaran di lembaga pendidikan anak usia dini tentu saja mempengaruhi penilaian yang diberikan oleh guru-guru di lembaga pendidikan anak usia dini (Khadijah \& Gusman, 2020). Dengan demikian, apabila penilaian tepat, maka menunjukkan hasil dari proses pendidikan yang berhasil.

Penilaian adalah upaya sistematik yang dilakukan melalui pengumpulan data atau informasi yang sahih (valid) dan reliabel, dan selanjutnya data atau informasi tersebut diolah sebagai pertimbangan pengambilan kebijakan program pendidikan (Sani, 2016). Penilaian merupakan suatu rangkaian kegiatan yang dilakukan oleh guru sebagai bagian dari sistem pengajaran yang direncanakan dan diimplementasikan di kelas yang mana di akhir kegiatan pembelajaran dilakukan penetapan keputusan mengenai hasil belajar atau pencapaian prestasi peserta didik (Sari \& Setiawan, 2020).

Penilaian portofolio pada dasarnya menilai karya-karya siswa secara individu pada rentang waktu tertentu untuk suatu mata pelajaran. Akhir suatu periode hasil karya tersebut dikumpulkan dan dinilai oleh guru dan peserta didik sendiri. Jadi, berdasarkan perkembangan tersebut, guru dan peserta didik sendiri dapat menilai perkembangan kemampuan peserta didik dan terus melakukan perbaikan dan dapat digunakan sebagai balikan untuk membelajarkan mereka kembali. Penilaian portofolio paling sering digunakan dalam lingkup PAUD, karena langsung menunjukkan dan mengukur sejauh mana keberhasilan kemampuan dan pemahaman anak (Selvi, 2020). Portofolio tersebut dibuat oleh guru berdasarkan tema dan subtema yang telah ditetapkan bersama. Portofolio dapat mengembangkan kreativitas anak usia dini sehingga kecerdasannya meningkat (Kemala \& Rohman, 2021). Oleh karena itu, berdasarkan penjelasan sebelumnya maka peneliti melakukan penelitian ini.

Penilaian portofolio mempunyai kelebihan dan kekurangan sebagai salah satu bentuk dari sebuah penilaian/asesmen. Kelebihan-kelebihan dari penilaian portofolio di antaranya: Memungkinkan pendidik mengakses kemampuan peserta didik untuk membuat, menulis, menghasilkan berbagai tipe tugas akademik; memungkinkan pendidik menilai keterampilan/kecakapan peserta didik; mendorong kolaborasi (komunikasi dan hubungan) 
antara peserta didik dan pendidik; memungkinkan pendidik mengintervensi proses dan menentukan di mana pendidik perlu membantu. Sedangkan, kekurangan dalam penilaian portofolio adalah sebagai berikut: Diperlukannya waktu yang relatif panjang dan segera; pendidik harus tekun, sabar, dan terampil; tidak ada kriteria yang standar (Arifin, 2016).

Portofolio dibagi menjadi dua jenis menurut yaitu Portofolio produk dan portofolio proses. Portofolio proses menunjukkan perkembangan peserta didik dari awal sampai akhir selama kurun waktu tertentu. Salah satu bentuk portofolio proses adalah portofolio kerja. Portofolio kerja digunakan untuk mengidentifikasi kelebihan dan kekurangan peserta didik dan memantau kemajuan peserta didik, sehingga guru dapat memperbaiki dan meningkatkan proses pembelajaran. Portofolio kerja juga dapat digunakan oleh peserta didik untuk menilai dirinya sendiri. Pada portofolio produk, menekankan peserta didik agar menguasai materi dari tugas yang diberi oleh guru (Wulan, 2020).

Petunjuk teknis penilaian portofolio terbagi menjadi perencanaan, pelaksanaan, dan acuan kualitas instrumen penilaian portofolio (Suryatiningsih, 2014). Perencanaan penilaian portofolio yaitu (1) Menentukan Kompetensi Dasar pada awal semester dan diinformasikan kepada peserta didik; (2) menentukan tujuan pembelajaran; (3) menjelaskan tujuan penggunaan, macam, dan bentuk portofolio; (4) menentukan kriteria penilaian; (5) menentukan format pendokumentasian, minimal memuat topik tugas portofolio, tanggal penilaian, dan catatan pencapaian portofolio; (6) menyiapkan map yang diberi identitas seperti nama peserta didik, kelas/semester, sekolah, mata pelajaran, dan tahun ajaran (Lopo et al., 2020).

Pelaksanaan penilaian portofolio yaitu: (1) Melaksanakan program pembelajaran, baik tugas terstruktur maupun tidak, sesuai tujuan pembelajaran; (2) melaksanakan penilaian portofolio sesuai kriteria penilaian; (3) hasil penilaian portofolio dicatat peserta didik; (4) hasil penilaian portofolio didokumentasikan sesuai format yang ditetapkan; (5) memberi umpan balik; (6) hasil karya diberi identitas, dikumpulkan, dan disimpan dalam map baik di rumah maupun di sekolah; (7) peserta didik diberi kesempatan untuk memperbaiki tugas jika hasil tersebut belum memuaskan; serta (8) memamerkan hasil karya. Acuan kualitas instrumen penilaian portofolio meliputi tugas dan rubrik (Ferdiana \& Pamungkas, 2019). Acuan tugas penilaian portofolio yaitu (1) sesuai dengan kompetensi dan tujuan pembelajaran; (2) berupa hasil tes, hasil tugas terstruktur, perilaku sehari-hari, dan dokumentasi aktivitas peserta didik; (3) memuat judul dan uraian tugas; serta (4) uraian tugas bersifat terbuka, sehingga portofolio beragam isinya. Acuan rubrik penilaian portofolio yaitu (1) memuat indikator; (2) mencakup kriteria penilaian sesuai isi tugas portofolio; (3) mudah digunakan oleh guru dan peserta didik; serta (4) bahasa yang digunakan mudah dipahami. Tugas dan rubrik merupakan instrumen dalam penilaian portofolio (Setiamiharja, 2016).

Penelitian ini berfokus pada Bagaimana Analisis Penilaian Portofolio yang dilaksanakan di TK Aisyiyah Bustanul Athfal I Pontianak. Penelitian dilakukan di TK Aisyiyah Bustanul Athfal I Pontianak karena lembaga ini mempunyai konseptual portofolio yang sistematis dan terstruktur. Penelitian ini fokus pada penilaian portofolio karena keterbatasan waktu dan keadaan yang terjadi ketika melakukan penelitian selama masa pandemi COVID-19 ini. Adapun subfokus penelitian meliputi Analisis perencanaan dan pelaksanaan penilaian portofolio di Kelas B TK Aisyiyah Bustanul Athfal I Pontianak.

\section{METODOLOGI}

Penelitian ini merupakan penelitian kualitatif. Metode penelitian kualitatif yang digunakan dalam penelitian ini pada kondisi objek yang alamiah serta gambaran langsung bagaimana penggunaan portofolio di TK Aisyiyah Bustanul Athfal I Pontianak (Sugiyono, 2016). Teknik pengumpulan data yang digunakan dalam penelitian ini adalah diutamakan dengan menggunakan wawancara dan dokumentasi. Teknik pengumpulan data dilakukan secara trianggulasi (gabungan), analisis data bersifat induktif/kualitatif, dan hasil penelitian kualitatif lebih menekankan pemahaman makna dan mengkonstruksi fenomena dari pada 
generalisasi. Pelaksanaan penelitian dilakukan dengan ada empat tahap, yaitu : (1) tahap sebelum ke lapangan, (2) tahap pekerjaan lapangan, (3) tahap analisis data, (4) tahap penulisan laporan.

Penelitian ini berdasarkan tahap-tahap. Adapun tahap-tahap penelitian dapat dilihat pada tabel 1.

Tabel 1. Tahap-Tahap Penelitian

\begin{tabular}{|c|c|c|c|c|}
\hline \multirow{2}{*}{ NO. } & \multirow{2}{*}{ KEGIATAN } & \multicolumn{3}{|c|}{ BULAN KE- } \\
\hline & & 1 & 2 & 3 \\
\hline 1. & Tahap sebelum ke lapangan & & & \\
\hline & a. Konsultasi proposal & $X$ & $\mathrm{X}$ & \\
\hline & b. Penyusunan proposal & $x$ & $x$ & \\
\hline & c. Administrasi perizinan & & & $\mathrm{X}$ \\
\hline 2. & Tahap Pekerjaan Memasuki Lapangan & & & \\
\hline & a. Melakukan fokus penelitian & & & $\mathrm{X}$ \\
\hline 3. & Melakukan Fokus Penelitian & & & $\mathrm{X}$ \\
\hline 4. & Tahap Penyeleksian Data & & & $\mathrm{X}$ \\
\hline 5. & Menganalisis Data & & & $x$ \\
\hline 6. & Uji Keabsahan Data & & & $\mathrm{X}$ \\
\hline 7. & Membuat Draf Laporan & & & $\mathrm{X}$ \\
\hline
\end{tabular}

Lokasi penelitian adalah tempat di mana penelitian akan dilakukan, untuk memperoleh data yang benar-benar dapat mendukung penelitian ini, dalam menentukan tempat penelitian tentunya mempertimbangkan ketersediaan data pendukung penelitian. Peneliti akan melakukan penelitian di TK Aisyiyah Bustanul Athfal 1 Pontianak yang beralamat di Jalan Camar. Variabel yang diamati dalam penelitian ini adalah Penilaian Portfolio yang dilaksanakan oleh TK Aisyiyah Bustanul Athfal I Pontianak. Penelitian ini dilaksanakan di TK Aisyiyah Bustanul Athfal I Pontianak karena lembaga ini mempunyai konseptual portofolio yang sistematis dan terstruktur yang bisa menjadi contoh dan panutan untuk lembaga TK lain.

Sumber data berdasarkan jenisnya terdapat dua jenis sumber data, yaitu pengumpulan data dengan menggunakan sumber primer dan sumber sekunder. Penentuan data primer didasarkan pada sumber primer yang dapat memberikan keterangan diharapkan peneliti secara keseluruhan. Sedangkan, data sekunder berupa data pendukung seperti dokumen atau data tertulis lainnya yang diperoleh dari berbagai sumber dan berkaitan dengan data penelitian. Sumber primer adalah sumber data yang langsung memberikan data kepada pengumpul data, dan sumber sekunder adalah sumber yang tidak langsung memberikan data kepada pengumpul data, misalnya lewat orang lain atau lewat dokumen. Sumber data primer adalah Kepala TK Aisyiyah Bustanul Athfal I Pontianak. Data sekunder merupakan data yang dapat memperkaya data primer, yang menjadi data sekunder atau data pendukung pada penelitian ini adalah guru serta dokumen atau data tertulis lainnya yang diperoleh dari berbagai sumber dan berkaitan dengan data penelitian.

Indikator instrumen dalam penelitian ini terbagi menjadi dua bagian yakni perencanaan dan pelaksanaan portofolio. Kriteria indikator intrumen perencanaan portofolio yakni 1) bentuk-bentuk portofolio yang dibuat oleh guru; panduan yang digunakan guru untuk memberikan portofolio pada anak; 3) penentuan tema dan subtema untuk materi portofolio anak. Sedangkan indikator instrumen pelaksanaan portofolio yakni 1) metode pembelajaran untuk melaksanakan penilaian portofolio; 2) kriteria penilaian portofolio; 3) hasil portofolio yang dikerjakan oleh anak-anak; 4) kekuatan dan kelemahan dari penilaian portofolio yang dilaksanakan di TK. 
Analisis data dilakukan sesuai dengan ketentuan penelitian kualitatif, yaitu diinterpretasikan dan dianalisis secara terus-menerus sejak awal hingga akhir penelitian. Dalam penelitian kualitatif analisis data dilakukan melalui tahapan sebagai berikut: Reduksi data, display data, dan verifikasi data. Kegiatan dalam analisis data meliputi: Data reduction, data display, dan conclusion drawing/verifying. Langkah-langkah analisis data penelitian ini ditunjukkan pada gambar 1 .

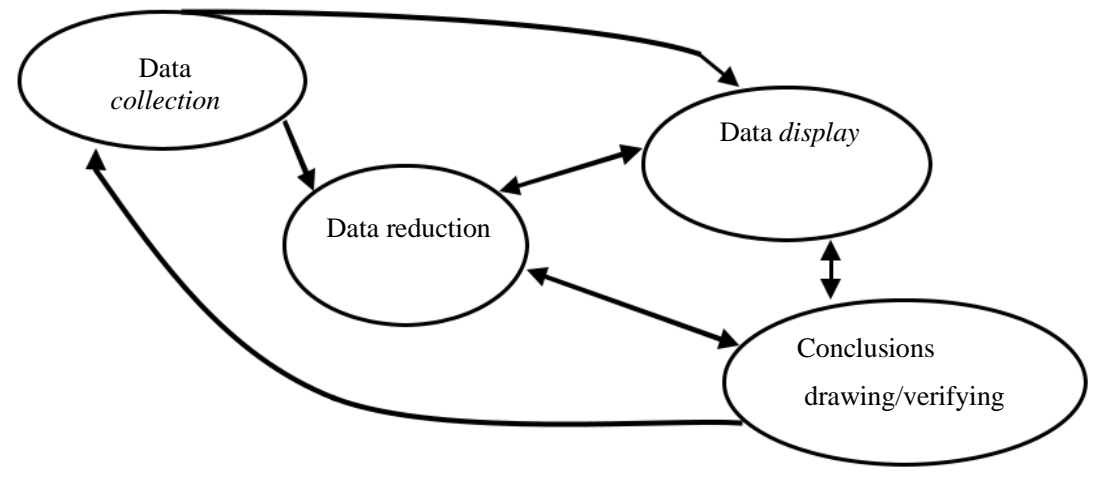

Gambar 1. Analisis Data Model Interaktif Miles and Huberman

Gambar 1. menggambarkan proses analisis dalam penelitian ini dengan menggunakan model Miles dan Huberman (Analysis Interactive Model) yang meliputi: data collection, data reduction, data display, conclusion (drawing/verifying) (Ayuni et al., 2020). Proses pengambilan data penelitian lapangan dengan menggunakan teknik wawancara, observasi, dan dokumentasi. Kemudian tahapan selanjutnya mereduksi data, dimana penelitian ini dilakukan dengan proses pemilihan, pemusatan perhatian pada penyederhanaan, pengabstrakan, dan transformasi data hasil penelitian dari lapangan. Tahap selanjutnya, penelitian ini melakukan penyajian data dengan mengumpulkan informasi tersusun yang memberi kemungkinan adanya penarikan kesimpulan dan pengambilan tindakan. Tahapan terakhir yakni, menarik kesimpulan atau verifikasi hasil dari penelitian (Zuniarsih et al., 2021).

\section{HASIL DAN PEMBAHASAN}

Penelitian ini dilaksanakan sejak pertengahan bulan September 2021 sampai dengan pertengahan November 2021 dan anak-anak belum melaksanakan pembelajaran secara penuh di sekolah, karena masih dalam situasi pemulihan dari pandemi COVID19. Penelitian dilakukan di kelas B TK Aisyiyah I Pontianak dengan pengumpulan data yang diutamakan pada dokumentasi. Selanjutnya, dalam pengumpulan data dilakukan pula wawancara dan observasi. Pada tahap awal penelitian, peneliti melakukan koordinasi dan observasi di TK Aisyiyah I pada tanggal 8 September. Penelitian dilakukan di pertengahan Oktober 2021 sampai dengan Awal Desember 2021. Peneliti lebih banyak berkonsultasi dengan Kepala Sekolah dan meneliti dokumen-dokumen yang terdapat di sekolah.

Peneliti mencatat jumlah anak per kelas adalah 15 orang anak sesuai dengan standar pendidikan anak usia dini. Jumlah keseluruhan anak laki-laki adalah 26 orang dan anak perempuan 19. Rincian jumlah anak usia dini per kelas adalah: (1) Kelas B1 diketahui anak laki-laki berjumlah 8 (delapan) orang dan anak perempuan berjumlah 7 (tujuh) orang; (2) Kelas B2 diketahui anak laki-laki berjumlah 8 (delapan) orang dan anak perempuan berjumlah 7 (tujuh) orang; dan (3) Kelas B3 diketahui anak laki-laki berjumlah 10 (sepuluh) orang dan anak perempuan 5 (lima) orang. Portopolio kelas B3 dapat dilihat pada gambar 2.

Hasil penelitian wawancara dengan masing-masing guru kelas menunjukkan bahwa perencanaan penilaian portofolio tiap kelas B terorganisasi (sama) berdasarkan Rencana Pelaksanaan Pembelajaran Mingguan (RPPM) yang telah ditetapkan oleh TK Aisyiyah Bustanul Athfal I Pontianak, artinya tugas-tugas tersebut disesuaikan dengan kegiatan pembelajaran yang dirancang oleh TK Aisyiyah Bustanul Athfal I Pontianak. Sedangkan, hasil 
wawancara tentang pelaksanaan penilaian portofolio Taman Kanak-kanak Aisyiyah Bustanul Athfal I Pontianak dinyatakan bahwa kegiatan pembelajaran hanya menggunakan RPPM karena kegiatan pembelajaran selama seminggu langsung diberikan (metode pemberian tugas).

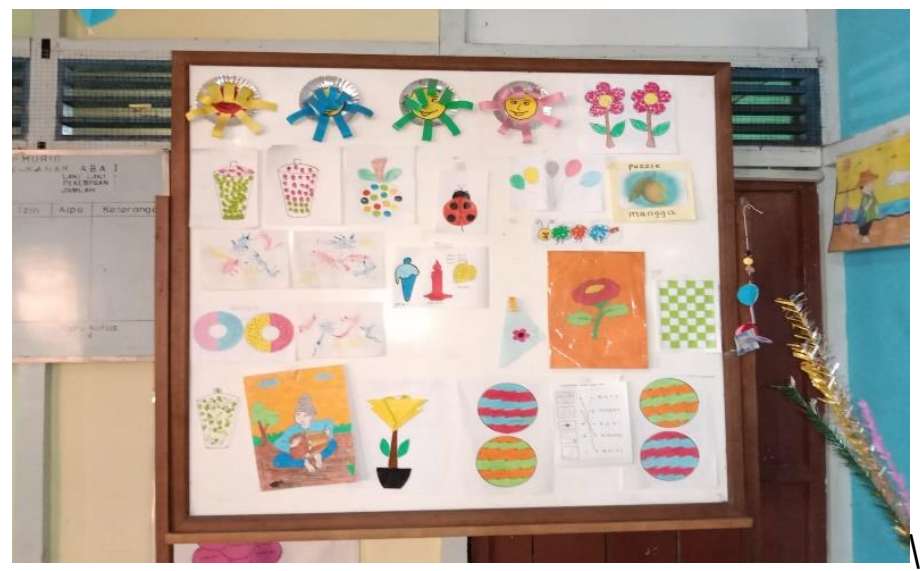

Gambar 2. Portofolio di Kelas B3

Jenis-jenis tugas cenderung diseragamkan berdasarkan petunjuk dari RPPM. Hasil portofolio (tugas-tugas) anak-anak usia dini itu dikumpulkan setiap hari Jumat karena dibagikan pada hari Senin. Adapun kegiatan-kegiatan pembelajaran yang menghasilkan portofolio dilaksanakan secara menyeluruh di antaranya meliputi: Mewarnai gambar, meniru dan melafalkan hadits, melompat dengan dua kaki atau satu kaki, memberi tanda < atau > pada buku paket, mengerjakan LKS, menghubungkan angka; menebalkan kata; menyalin kata, dapat menyebutkan nama TK Aisyiyah Bustanul Athfal, menulis garis lengkung kanan dan kiri, menghitung jumlah gambar, menebalkan tulisan sesuai dengan gambar anggota keluarga, dapat bercakap-cakap tentang keluarga inti, mengenal aturan shalat, menirukan dan melafalkan surat Al Kautsar, menuliskan nama-nama tanaman bunga, menceritakan manfaat bunga, memberi tanda pada anak yang memperlakukan tanaman dengan baik dan yang tidak memperlakukan tanaman dengan baik, melipat kertas membentuk bunga, menyebutkan tempat-tempat sholat, menirukan dan melafalkan surat Al Ikhlas, menggunting dan menempel gambar, menghubungkan angka, mengurutkan cerita, mengetahui makanan ayam, menempel guntingan kertas, menggunting pola, menghitung jumlah penumpang, melengkapi kata, menempel bentuk perahu layar dari kertas origami, dan lain-lain.

Persiapan yang dilakukan oleh guru adalah menyiapkan lembar RPPM untuk beberapa anak usia dini sesuai dengan jumlah anak per kelas. Lembar RPPM tersebut dibagikan kepada orangtua anak usia dini untuk dikerjakan di rumah masing-masing. Lembar RPPM biasanya juga dilengkapi oleh lembar kerja berupa gambar untuk diwarnai, pertanyaan untuk dijawab, gambar untuk ditempel, dan sebagainya. Rencana Pelaksanaan Pembelajaran Mingguan (RPPM) tersebut ditetapkan berdasarkan hasil Rapat Kepala PAUD dengan para guru. Tema-tema ditentukan dari indikator pencapaian perkembangan anak yang akan dikembangkan dan ditingkatkan. Penyusunan portofolio diseragamkan mengingat untuk memudahkan guru-guru di TK Aisyiyah Bustanul Athfal I Pontianak karena masih dalam keadaan pandemi COVID-19 dan penilaian portofolio dilakukan oleh guru kelas masingmasing.

Penilaian portofolio di kelas B1, B2, dan B3 secara umum telah dilakukan dengan "baik" mengingat selama masa pandemi COVID-19 yang sampai dengan masa pemulihan dari pandemi COVID-19 saat ini bahwa pembelajaran belum maksimal seperti sebelum masa pandemi COVID-19. Portofolio berhasil dengan baik karena sesuai dengan kriteria indikator penilaian, yakni portofolio di TK ABA I Pontianak mencakup semua aspek 1) bentuk portofolio yang dibuat oleh guru; panduan yang digunakan guru untuk memberikan 
portofolio pada anak; 3) penentuan tema dan subtema untuk materi portofolio anak. Bentuk portofolio yang dimuat ke dalam RPPM, panduan yang digunakan guru disesuaikan dengan sesuai dengan STPPA, penentuan tema dan subtema berdasarkan kurikulum yang digunakan yakni kurikulum 2013. Pelaksanaan penilaian portofolio dan contoh portofolio dapat dilihat pada gambar 3 dan 4 .

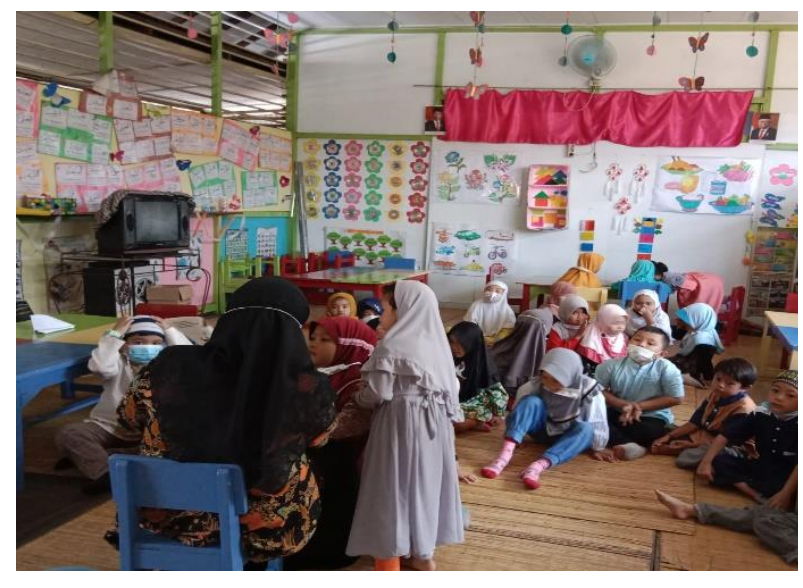

Gambar 3. Pelaksanaan Penilaian Portofolio (Keadaan Kelas B2)

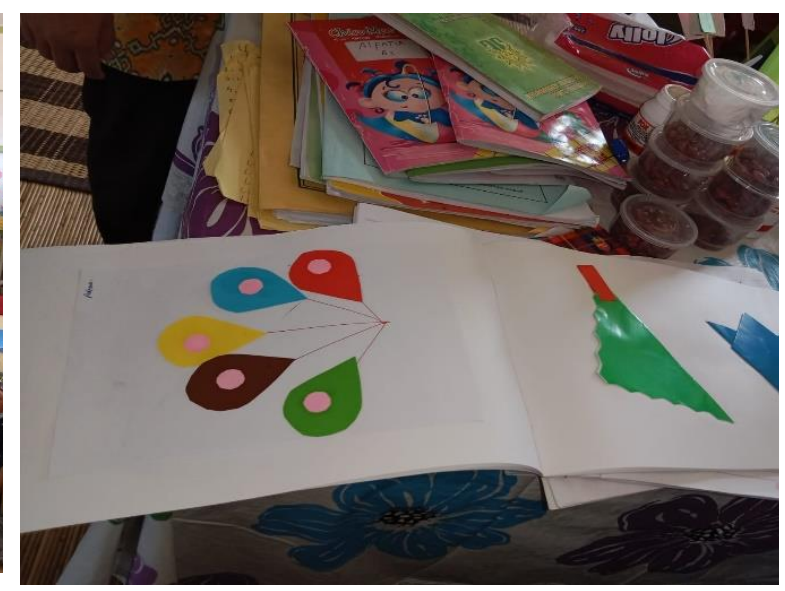

Gambar 4. Contoh Portofolio di Kelas B2

Penelitian hari pertama di tanggal 8 September 2021 yang mana peneliti berkoordinasi dengan Kepala TK Aisyiyah Busthanul Athfal I Pontianak dan observasi lingkungan TK Aisyiyah Busthanul Athfal I Pontianak itu sambil merekam beberapa gambar yang diperlukan. Hasil wawancara I dengan Kepala TK Aisyiyah Busthanul Athfal I pada hari itu juga menunjukkan bahwa penilaian seperti itu dilakukan hanya ketika situasi pandemi masih mencemaskan, namun jika telah aman maka mengikuti pembelajaran seperti biasa sama seperti sebelum masa pandemi COVID-19 berlangsung. Peneliti menemukan bahwa portofolio-portofolio yang dibuat guru untuk diberikan kepada anak-anak pada dasarnya sudah sesuai dengan Standar Tingkat Pencapaian Perkembangan Anak (STPPA) berdasarkan perkembangan usia anak di kelas B. Tugas-tugas portofolio tersebut disusun dari Rencana Pelaksanaan Pembelajaran Mingguan (RPPM) didasarkan pada Program Semester (Prosem).

Jadi, selama masa pandemi COVID-19, guru-guru hanya berpedoman pada RPPM atau tidak menggunakan Rencana Pelaksanaan Pembelajaran Harian (RPPH) karena efisiensi yang mana tugas sekaligus diberikan pada hari Senin - Jumat, dan pada hari Jumat dikumpulkan kemudian begitulah seterusnya orangtua mengambil tugas pada hari Senin untuk Minggu depan dan mengumpulkan tugas-tugas yaitu hari Jumat depannya lagi. Portofolio-portofolio dari anak-anak kelas B, baik kelas B1, B2, B3 dibuat dan disusun oleh guru kelas masing-masing sesuai dengan tema yang telah ditentukan dari TK Aisyiyah Busthanul Athfal I Pontianak.

Peneliti melihat portofolio-portofolio tersebut cukup lengkap walaupun tidak semua anak dapat menyelesaikannya dengan baik karena tidak semua anak akan mendapat bimbingan dan pengawasan yang intensif dari orangtua anak-anak tersebut ketika mengerjakan portofolio-portofolio tersebut di rumahnya masing-masing. Portofolioportofolio itu dalam berbagai bentuk tugas (seperti: Menggunting, menempel, mewarnai, menggambar, mengerjakan soal berhitung, dan membaca serta menulis huruf). Portofolio yang dikerjakan oleh anak-anak kelas B menggunakan RPPM yang dibagikan dalam bentuk lembar tugas untuk satu Minggu. Format lembar RPPM tersebut sudah diseragamkan dengan TK Aisyiyah Bustanul Athfal lainnya. Lembar RPPM tersebut mudah dipahami oleh orangtua sehingga dapat langsung dikerjakan oleh anak usia dini. 
Metode pembelajaran yang dilaksanakan selama masa pandemi COVID-19 adalah pemberian tugas. Hal itu dilakukan menyesuaikan dengan keadaan pandemi yang terjadi di seluruh dunia karena prosedur kesehatan dari pemerintah Indonesia. Pelaksanaan penilaian portofolio di TK Aisyiyah Bustanul Athfal I tidak berdasarkan standar khusus, yang mana hanya menilai berdasarkan empat kriteria. Empat kriteria tersebut adalah: (1) Aktivitas/hasil karya anak; (2) Catatan Guru; (3) Analisis Kompetensi Dasar (KD) yang dimuat dalam Kurikulum 2013 PAUD; dan (4) Kemampuan yang dicapai oleh anak apakah berada pada kategori BB (Belum Berkembang); MB (Mulai Berkembang); BSH (Berkembang Sesuai Harapan); dan BSB (Berkembang Sangat Baik). Hasil portofolio yang dikerjakan anak-anak usia dini secara umum pada kategori "baik" sesuai dengan empat kriteria di tersebut dan masuk katgori Berkembang Sesuai Harapan, karena hampir semua portofolio dapat diselesaikan anak walaupun terdapat sebagian kecil anak dari tiga kelas tidak tuntas mengerjakan portofolio yang mungkin disebabkan kurang motivasi dan kurang pemahaman dalam mengerjakan tugas dari anak usia dini ataupun orangtua kurang mendukung dalam pengerjaannya (kurang memperhatikan atau tidak memeriksa).

Pelaksanaan penilaian portofolio di TK Aisyiyah Bustanul Athfal I Pontianak tersebut mempunyai kekuatan dan kelemahan. Kekuatan dari pelaksanaan penilaian portofolio di Kelas B TK Aisyiyah Bustanul Athfal I Pontianak adalah: (1) Keseragaman format penilaian menurut RPPM; (2) Kepala TK Aisyiyah Bustanul Athfal I Pontianak memberikan arahan dan pemeriksaan; (3) Koordinasi para guru Kelas B dan Kepala TK sangat baik; (4) Koordinasi dan kerjasama guru dengan orangtua sangat baik yang dilakukan baik secara offline maupun secara online; dan (5) Berkas portofolio langsung dinilai guru ketika anak sudah mengerjakan. Sedangkan, kelemahan pelaksanaan penilaian portofolio di TK Aisyiyah Bustanul Athfal I Pontianak adalah: (1) Belum disusunnya format khusus penilaian portofolio; (2) Dokumen portofolio yang disusun masih sederhana (terdiri atas dua lembar yaitu indikator perkembangan yang akan dicapai dan lembar pemantauan kegiatan anak yang diisi oleh orangtua); dan (3) Seleksi hasil karya tidak dilakukan karena keadaan yang kurang mendukung. Oleh karena itu, berdasarkan hasil analisis maka peneliti menilai bahwa pelaksanaan penilaian portofolio di kelas B TK Aisyiyah Bustanul Athfal I tergolong "baik".

Hal ini selaras dengan hasil penelitian sebelumnya yang membuktikan bahwa portofolio sangat baik untuk diterapkan di TK, akan tetapi hasil penelitian (Wulan, 2020) memiliki perbedaan dengan yang peneliti lakukan yakni penelitian ini fokus pada pengembangan kemampuan motorik halus. Sedangkan penelitian yang peneliti lakukan berbeda dengan penelitian lain, karena penelitian ini fokus pada implementasi portofolio untuk semua aspek perkembangan melalui metode pengajaran pemberian tugas kepada anak. Ditinjau dengan hasil penelitian lain, (Lopo et al., 2020) meneliti tentang penggunaan portofolio di PAUD Laismanekat Nasipanaf. Hasil penelitian tersebut cukup berhasil diterapkan akan tetapi namun masih diperlukan pembenahan dalam penggunaan pedoman penilaian yang ada.

Berdasarkan beberapa hasil penelitian terdahulu tersebut, dapat diketahui bahwa memiliki perbedaan cukup signifikan dengan hasil penelitian yang peneliti lakukan. Penelitian yang peneliti lakukan di kelas B TK Aisyiyah Bustanul Athfal I memperoleh kategori baik dan berhasil diterapkan di TK. Penggunaan portofolio dalam penelitian ini dilakukan sesuai dengan sesuai dengan Standar Tingkat Pencapaian Perkembangan Anak (STPPA). Sistematika portofolio terstruktur di dalam RPPM didasarkan pada Program Semester (Prosem) dan menggunakan metode pengajaran pemberian tugas kepada anak. Sehingga penilaian menggunakan portofolio di TK Aisyiyah Bustanul Athfal I dilaksanakan dengan berhasil dan dapat digunakan di TK.

Implikasi dari penggunaan portofolio di TK Aisyiyah Bustanul Athfal I adalah mampu memberi gambaran atau pandangan guru dalam menilai tentang sejauh mana kemampuan dan perkembangan anak, dapat digunakan guru sebagai catatan jangka panjang, dan membantu mengidentifikasi kelemahan, kelebihan anak, serta merancang strategi mencapai 
DOI: $10.31004 /$ obsesi.v6i4.2396

kompetensi peserta didik yang diharapkan. Kemudian portofolio bisa menjadi sumber informasi guru untuk membuat pembaharuan dari proses pembelajaran. Portofolio memungkinkan anak untuk menyajikan pekerjaannya lebih dari satu kali untuk menunjukkan kemajuan mereka dalam mencapai tujuan pembelajarannya.

\section{SIMPULAN}

Penilaian menggunakan portofolio di TK memberikan manfaat yang besar terutama dalam perkembangan anak usia dini. Penelitian ini menghasilkan beberapa hal penting. Adapun beberapa hal penting tersebut berdasarkan analisis peneliti adalah: Perencanaan dan pelaksanaan penilaian portofolio dapat dinyatakan "baik" dan "efektif" karena portofolio dapat memotivasi anak serta orangtua untuk meningkatkan prestasi belajar anak usia dini. Lembaga TK perlu merancang dan menyusun dokumen penilaian portofolio secara khusus sehingga dapat menjadi pedoman guru dalam menetapkan penilaian untuk anak usia dini sesuai dengan pertumbuhan dan perkembangannya. Penyusunan portofolio dapat dikembangkan lagi mengikuti kemajuan ilmu pengetahuan dan teknologi sesuai dengan bidang pendidikan anak usia dini.

\section{UCAPAN TERIMA KASIH}

Penulisa mengucapkan terima kasih kepada Kepala Sekolah dan dewan Guru TK Aisyiyah Bustanul Athfal I serta orang tua murid atas kesempatan yang diberikan pada peneliti untuk melakukan penelitian. Terima kasih juga kepada semua pihak yang telah membantu sehingga artikel ini dapat dipublikasikan.

\section{DAFTAR PUSTAKA}

Arifin, Z. (2016). Evaluasi Pembelajaran. PT Remaja Rosdakarya.

Ayuni, D., Marini, T., Fauziddin, M., \& Pahrul, Y. (2020). Kesiapan Guru TK Menghadapi Pembelajaran Daring Masa Pandemi Covid-19. Jurnal Obsesi : Jurnal Pendidikan Anak Usia Dini, 5(1). https:// doi.org/10.31004/obsesi.v5i1.579

Chiodini, J. (2020). Online learning in the time of COVID-19. Travel Medicine and Infectious Disease, 34, 101669. https://doi.org/10.1016/j.tmaid.2020.101669

Fauziddin, M., Mayasari, D., \& Rizki, L. M. (2021). Effective Learning for Early Childhood during Global Pandemic. AL-ISHLAH: Jurnal Pendidikan, 13(1), 515-522. https://doi.org/10.35445/alishlah.v13i1.458

Ferdiana, M. D., \& Pamungkas, D. (2019). Penggunaan Penilaian Berbasis Kelas dan Portofolio dalam Menumbuhkan Minat Baca. Alinea: Jurnal Bahasa, Sastra, Dan Pengajaran, 8(2). https://doi.org/10.35194/alinea.v8i2.549

Kemala, A., \& Rohman, A. (2021). Penilaian Perkembangan Anak Selama Belajar dari Rumah di Era Pandemic Covid-19. Jurnal Obsesi : Jurnal Pendidikan Anak Usia Dini, 6(2). https://doi.org/10.31004/obsesi.v6i2.1129

Khadijah, K., \& Gusman, M. (2020). Pola Kerja Sama Guru dan Orangtua Mengelola Bermain AUD Selama Masa Pandemi Covid-19. Kumara Cendekia. https://doi.org/10.20961/kc.v8i2.41871

Lopo, R. J. K., Masitoh, S., \& Hariastuti, R. T. (2020). Implementasi Penilaian Berbasis Portofolio di PAUD Laismanekat Nasipanaf. Jurnal Pelita PAUD, 4(2), 187-196. https://doi.org/10.33222/pelitapaud.v4i2.970

Lučić, L. (2020). Effects of COVID-19 related restrictive measures on parents of children with developmental difficulties. Journal of Children's Services. https://doi.org/10.1108/JCS-07-2020-0041

Menteri Kesehatan RI. (2020). Peraturan Menteri Kesehatan Republik Indonesia Nomor 9 Tahun 2020 Tentang Pedoman Pembatasan Sosial Berskala Besar Dalam Rangka Percepatan Penanganan Corona Virus Disease 2019. Parallax. 
Oktaviana, A., \& Srianggita, I. (2021). Cognitive Development of Children Aged 4-7 Years During The Covid-19 Pandemic. JOYCED: Journal of Early Childhood Education, 1(2), 127-138. https:// doi.org/10.14421/joyced.2021.12-06

Sani, R. A. (2016). Penilaian Autentik. Bumi Aksara.

Sari, K. M., \& Setiawan, H. (2020). Kompetensi Pedagogik Guru dalam Melaksanakan Penilaian Pembelajaran Anak Usia Dini. Jurnal Obsesi : Jurnal Pendidikan Anak Usia Dini, 4(2). https://doi.org/10.31004/obsesi.v4i2.478

Satgas COVID-19. (2021). Analisis Data Covid-19 Indonesia. Analisis Data COVID-19 Indonesia.

Selvi, I. D. (2020). Implementation of Assessment for Islamic and Catholic Religious Values Development. Indonesian Journal of Early Childhood Education Studies, 9(1). https:// doi.org/10.15294/ijeces.v9i1.38007

Setiamiharja, R. (2016). Penilaian Portopolio Dalam Lingkup Pembelajaran Berbasis Kompetensi. EduHumaniora | Jurnal Pendidikan Dasar Kampus Cibiru, 3(2). https:// doi.org/10.17509/eh.v3i2.2806

Sugiyono. (2016). Kuantitatif, Kualitatif, dan R\&D. Bandung: Alfabeta.

Suryatiningsih, S. (2014). Model Layanan Monitoring Perkembangan Anak. Jurnal Informatika,Telekomunikasi Dan Elektronika, 6(1). https:// doi.org/10.20895/infotel.v6i1.67

Suyadi, \& Selvi, I. D. (2022). Online learning and child abuse: the COVID-19 pandemic impact on work and school from home in Indonesia. Heliyon, 8(1), e08790. https:// doi.org/10.1016/j.heliyon.2022.e08790

Tommasel, A., Rodriguez, J. M., \& Godoy, D. (2019). An experimental study on feature engineering and learning approaches for aggression detection in social media. Inteligencia Artificial, 22(63). https:// doi.org/10.4114/intartif.vol22iss63pp81-100

Wulan, D. S. A. (2020). Penggunaan Portofolio dalam Penilaian Perkembangan Motorik Halus Anak Usia Dini di PAUD Al Wafi Kecamatan Selesai Kabupaten Langkat. Jurnal Usia Dini, 6(2). https:// doi.org/10.24114/jud.v6i2.22189

Zuniarsih, Z., Maemonah, M., \& Dwi Selvi, I. (2021). Love Cards: Media Orang Tua Menerapkan Perilaku Hidup Bersih dan Sehat pada Anak Usia Dini di Masa Pandemi COVID-19. Golden Age: Jurnal Ilmiah Tumbuh Kembang Anak Usia Dini, 6(2), 57-66. https:// doi.org/10.14421/iga.2021.62-01 